\title{
Pilgrimage, Material Objects and Spontaneous Communitas
}

\begin{abstract}
Based on an ethnographic study of Lourdes, we contribute to tourism discussion on religious pilgrimage and communitas. Taking a material perspective, we prioritise spontaneous over normative communitas, and materiality over intangibility. We adopt the lens of tangible communitas to unpack the role of material objects in extending communitas beyond the spatial confines of the pilgrimage site. We explore how spontaneous communitas manifests in the material objects brought home from and left behind at the pilgrimage site. This reveals the portability of communitas and how it can be de-coupled from liminality and experienced in normative structure. The paper's focus on religious materiality also offers a renewed understanding of the extra-discursive importance of religious kitsch materiality.
\end{abstract}

\section{KEYWORDS}

Pilgrimage, communitas, materiality, kitsch, ethnography

\section{INTRODUCTION}

Pilgrimage is both "the oldest form of tourism" (Rinschede, 1992, p. 53) and the fastest growing motivation for travel (Coningham, 2016). Previous research on pilgrimage has emphasised the intangible experience and revealed how they involve emotion and selftransformation (Andriotis, 2009; Belhassen et al., 2008; Buzinde et al., 2014; CollinsKrenier, 2010; Dubisch and Winkelman, 2005; Gilmore, 2005; Hudman and Jackson, 1992; Jackowski and Smith, 1992; Terzidou, Scarles and Saunders, 2017, 2018). Together this work effectively demonstrates "the multiplicity and colourfulness of religiousness" within various sacred spaces (Terzidou et al., 2017, p. 127). Although less research has considered the role of material objects in pilgrimage, there is recognition that the spiritual and material coexist (e.g. Kaufman, 2005; Santana and Botelho, 2019; van Lear and Izberk-Bilgin, 2019;

Vásquez, 2011). In this paper, we build on literature in this area with a specific focus on materiality and communitas.

Communitas is defined as a temporal form of social anti-structure (Turner and Turner, 1978). During communitas normative social structure, age, gender and social class are all cast off, and people are temporarily liberated from their usual identities and conventional, structuralized norms. Pilgrimage scholars have explored whether and how communitas manifests in experiential and intangible ways (Eade, 1992; Morinis, 1992; Pfaffenberger, 1979; Reader and Walter, 1993; Sallnow, 1981). This work tends to prioritise normative communitas over other forms. We build on this research by prioritising spontaneous over normative communitas, and materiality over intangibility. To do so we adopt the lens of tangible communitas (Cox, 2018), a spontaneous form of communitas that allows us to unpack the role of material objects in extending communitas beyond the spatial confines of the pilgrimage site. We address the following two research questions: How does spontaneous communitas manifest in the material objects brought home from the pilgrimage site? How 
does spontaneous communitas manifest in the material objects left behind at the pilgrimage site?

Our study is based on an ethnography of the Catholic pilgrimage site of Lourdes. Nestled in the Pyrenees of France, Lourdes was virtually unknown prior to 1858 when a series of apparitions began between peasant girl Bernadette Soubirous, who was later to be canonized as St Bernadette, and a lady who was authenticated in 1862 by the Catholic Church as Our Lady, the Mother of Jesus Christ. The apparitions, which took place in a cavernous rock now known as the Grotto of Massabielle, led to the discovery of a water source stemming from the river Gave, which many believe to be the catalyst for miraculous healing and renewal. Consequently, Lourdes has become a beacon for both ill and healthy pilgrims. Lourdes is the second biggest tourist destination in France and the third largest Catholic pilgrimage site in the world (following the Vatican in Rome and Our Lady of Guadeloupe in Mexico). Its religious landscape encompasses 52 hectares of churches, basilicas and spiritual centres (Fargues, 2011). Separated only by a set of gates and a small road, Lourdes offers a bustling marketplace, including a plethora of services for accommodation, entertainment, food and souvenirs.

In the next section, we provide the theoretical underpinnings for the study. This is followed by a description of the research methods used to capture the role of material objects at Lourdes. We present findings based on our two research questions, before concluding with how our study advances knowledge on the capacity of communitas within pilgrimage tourism scholarship.

\section{LITERATURE}

The literature review is presented in three sections. First, we review the literature on communitas. Second, we discuss the literature on pilgrimage and material objects. Third, we consider literature on the interaction between the pilgrimage site and the home environment.

\section{Communitas}

Communitas is defined as a temporal form of social anti-structure (Turner and Turner, 1978). Aligned with communitas is the concept or status of liminality. Stemming from the work of Van Gennep (1969), liminality refers to being in a transitionary state, "betwixt and between the positions assigned and arrayed by law, custom, convention and ceremonial" (Turner, 1969, p. 95). Indeed, from a Turnernian perspective "the most significant aspect of liminality is its capacity to generate communitas" (Roseman and Badone, 2004, p. 3). Contrary to the involuntary, forced nature of liminal experiences, pilgrimage is described as a voluntary and liminoid experience (Turner and Turner, 1978). Turner and Turner's (1978) seminal work suggests that pilgrims welcome the sense of escape from prevailing social structures, permitting them a liminoid status and in turn temporal experiences of communitas.

For some researchers, this is an overly romanticized understanding that obscures the tensions that are inherent in pilgrimage (Eade, 1992; Greenfield and Cavalcante, 2005; Husemann et al. 2016; Pfaffenberger, 1979; Sallnow, 1981). For example, Eade's (1992, p. 25 ) research on Lourdes reveals only a "superficial commonality" amidst the hierarchical differentiation and organization of pilgrims. Greenfield and Cavalcante (2005) found no evidence of communitas during pilgrimages to the shrine of St Francis in Brazil. Rather, pilgrims focused on themselves and their personal motivations for undertaking the journey.

Di Giovine (2011, p. 262) offers an alternative argument that outlines a "hopeful" relationship between contestation and communitas, suggesting that both "dialectically inform each other" and "keep each other in check." This perspective resonates with Turner's (1969, 
1982) assertion that communitas should not be interpreted as a reversal to, but rather in dialogue with structure:

"Structural action swiftly becomes arid and mechanical if those involved in it are not periodically immersed in the regenerative abyss of communitas. Wisdom is always to find the appropriate relationship between structure and communitas under the given circumstances of time and place, to accept each modality when it is paramount without rejecting the other, and not to cling to one when its present impetus is spent" (Turner 1969, p. 139).

Turner $(1969,1982)$ outlines the need to differentiate between different forms of communitas. He offers three forms of interrelated communitas - spontaneous (also known as existential), normative and ideological. Spontaneous communitas refers to a "happening" or event that sparks a complete undiluted separation from social structure. Turner (1982) believes that the spontaneity of communitas is unsustainable and becomes normative. Normative communitas refers to the need to organize resources and maintain social control and acceptable norms. Ideological communitas refers to the ideological tenants and utopian models that drive normative communitas, for example, the religious precepts of salvation within Catholicism that drive the pilgrimage of Lourdes. Given the structures built around popular pilgrimage sites, scholars have privileged normative communitas over other forms. Despite Reader's (1993) call for research to consider subtler and individual forms of communitas, normative understandings of communitas continue to dominate. In profiling tangible communitas (Cox, 2018), we prioritize spontaneous communitas and shed light on the subtle and individual forms of communitas alluded to by Reader (1993).

Tangible communitas is a form of spontaneous communitas that is dependent on material culture (Cox, 2018). It emerged from Cox's (2018) investigation of the Los Angeles Wisdom Tree and the associated ritual of leaving material culture in the form of notes, letters and other objects at the tree. Cox (2018) conceptualizes the journey to the tree as a spiritual pilgrimage and suggests that the material culture left behind is the basis for an imagined community. Unlike Turner's (1969) communitas that involves groups coming physically together in a particular place, Cox's (2018) tangible communitas is characterized by indirect interaction, detachment and spontaneous experiential connection. As aforementioned, scholarly discussion of communitas has privileged the intangible experience. This has in turn neglected to understand the relationship between communitas and material objects. Cox's (2018) work is therefore an important exception. However, although prioritising materiality, Cox's (2018) version of tangible communitas is rooted to interaction with a fixed location (the Los Angeles Wisdom Tree). We endeavour to explore more readily the portability of communitas and how it manifests through both material objects purchased to bring home and material objects left behind at pilgrimage sites.

\section{Pilgrimage and Material Objects}

Religious material culture "consists of the objects, spaces, practices, and ideas in which belief takes shape" (Morgan 2010, p. 73). We are particularly concerned with objects associated with pilgrimage sites. The commercial marketplace for religious materiality can be traced to the $11^{\text {th }}$ century (Turner and Turner, 1978), however its expansive growth in recent decades is attributed to industrialization and mass production (Kaell, 2012; Kaufman, 2005). 
Indeed, Reader (2014) argues that today's consumer culture has enhanced, not initiated, commerciality within pilgrimage. Nonetheless, there is little consensus on how commercialisation impacts on the pilgrimage experience. Some scholars position the market and religion as opposing forces. For example, research suggests that the commercial environment "disenchants" (Husemann et al. 2016, p. 3365) or "infects" (Scott and Maclaren, 2013, p. 206) pilgrimage experiences. These tensions can create a dissonance between the pilgrim's prior expectations of the sacred site and the reality they encounter (Caidi, 2019). In contrast, other research has discussed commercialisation more positively.

Reader (2014, p. 22) believes pilgrimage to involve the "interweaving of piety, play and purchasing". He argues that belief in a dichotomy between sacred and profane, alongside assertions of the sacred being "despoiled and undermined" (2014, p. 10) by commerciality, are inaccuracies that delimit pilgrimage scholarship. Furthermore, Terzidou et al. (2017) argue that tourist moments and activities have a central role in pilgrimage that overcome sacred and secular differentiations. Thomas, White and Samuel (2018) find that communitas can be found in both the sacred and secular spaces of Lourdes, whilst Higgins and Hamilton (2019) outline the therapeutic role played by the marketplace in providing pilgrims compensation from socio-cultural dilemmas. Together this body of research supports Coleman and Eade's $(2018$, p.4) assertion that pilgrimage is more than the "set-apart, sacred realm" but includes a "network of mundane servicing mechanisms". From this perspective, spiritual and material aspects of the pilgrimage co-mingle to enhance the overall experience (Kaufman, 2005).

Jesus Junk, Holy Hardware, and Christian Kitsch are derogatory descriptors of religious objects consumed at Christian pilgrimage sites (McDannell, 1995). These religious objects have been described as "an inappropriate mixing of the sacred and the profane" (Belk, Wallendorf and Sherry, 1989, p. 25) and "kitsch of the worst kind" (Strausberg, 2011, p. 210). Indeed, Eade (1992, p. 27) during his 22-year ethnography in Lourdes, uncovered popular views of such objects to be in "bad-taste" and signs of "gullibility and unsophistication". This resonates with Dorfles' (1969) concerns that religious kitsch objects lead people away from rather than towards religion. However, more recently, Kaufman (2005, p. 11) argues that mass-produced objects enhance rather than detract from the pilgrimage and suggests that material objects are "essential intermediaries for pilgrims seeking to receive God's grace." This aligns with Di Giovine (2012) and Reader's (2014) suggestion that mass-produced religious objects can have similar symbolic function as relics. Further, Moufahim and Lichrou (2019) highlight how religious objects enable pilgrims to visually symbolize and identify their spiritual sense of self. Such material objects serve both as identity markers and tools permitting pilgrims to interact and better understand the Sacred (Pinto, 2007). From this perspective, the boundary between commodity and sacred object is fluid (Kaell, 2012).

Less research has focused on material objects left behind at pilgrimage sites, although votive offerings or ex-votos have attracted attention. Votive offerings are central to the material culture of pilgrimage and relate to a "reciprocal spiritual contract" between the pilgrim and sacred figures (King, 2005, p. 49). For example, Turley's (2013) investigation of goods left behind at the shrine of St. Bridget's Well in Ireland reveals that these goods act as material requests for spiritual intervention. A further example is Santana and Botelho's (2018) work on Juazeiro do Norte in Brazil who uncover that leaving behind objects at the pilgrimage site represents, not requests, but rather gratitude and payment to deity for intervention. Ex-votos of this nature have an important therapeutic role as they become a tangible means of cathartic release (King, 2005). These studies align with the economy of salvation, which involves the leaving behind of material objects at pilgrimage sites as a means of establishing "a series of obligations between those on earth and those in Heaven" 
(McDannell, 1995, p. 140). Votive offerings left within sacred places connects "private devotional practices at home with public performances at the pilgrimage site" (Notermans and Jansen, 2011, p. 172). This relationship between home and the pilgrimage site is explored further in the next section.

\section{Pilgrimage and Home}

The Turnerian perspective on pilgrimage points towards a binary relationship between the pilgrimage site and the home environment. For example, some pilgrims gain a sense of spiritual authenticity (Moufahim and Lichrou, 2019), others benefit from deceleration (Husemann and Eckhardt, 2019), and others experience emotional release (Higgins and Hamilton, 2019). This research stream demonstrates that the physical and geographical separation between the pilgrimage site and the home permits a sense of wholeness and healing (Preston 1992, p. 34). However, this Turnerian perspective neglects aspects that fall outside the ritualised pilgrimage journey (Winkelman and Dubisch, 2005). Indeed, Bajc, Coleman and Eade (2007, p. 327) define pilgrimage as a relational and social phenomenon, dependent not on a particular site but rather on "the interactions that emerge between people, places, times and imaginaries". They continue that research needs to understand movements towards and away from pilgrimage centres, how such centres are delocalised from their fixed locations, and "translated to new places, at different scales" (2007, p. 328).

We recognise this critique and suggest that a bounded perspective on pilgrimage overlooks the symbiotic relationship between the pilgrimage site and the home environment. This aligns with Carr's (2002) argument that the interaction between tourist and residual cultures should be recognised, and Larsen's (2008, p. 21) critique of inaccurate dualisms that position tourism and everyday life as "different ontological worlds." Although the home is physically left behind, it remains intrinsic to the pilgrimage experience (Reader, 2014). Thus, the sacred pilgrimage site and home should be "understood relationally, as extensions rather than comparisons of each other" (Caidi, 2019, p. 63). A prime example is Belhassen's (2009) research on evangelical pilgrimages that demonstrates how pilgrimages are contextualised in relation to broader socio-political, cultural, behavioural and theological issues. Frey's (2004) research on the Camino de Santiago pilgrimage reveals that, on their return home, some pilgrims seek to continue their pilgrimage but many are quickly reincorporated into societal structures that bracket the pilgrimage experience. This resonates with the discovery from Buzinde et al. (2014) that pilgrims often struggle to connect with their faith upon reincorporation home.

Thus, we are interested in how material objects can support such reincorporation. Defined as tangible transporters to intangible experiences (Anderson and Littrell, 1995), souvenirs have transformative and connective abilities enabling reflection and development of a sense of self (Haldrup, 2017). From this perspective, mass-produced material objects can enhance "spiritual ties" between the home and the pilgrimage site (Kaufman, 2005, p. 55). Indeed, Spackman (2005, p. 414) describes souvenirs as "carriers of remembrance" and "proofs of passage" of a pilgrimage experience. Similarly, Kaell (2014, p. 174) uncovers how material souvenirs from the Holy Land help to "solidify" the pilgrimage experience once home. Haldrup (2017) shares that although emplaced in the home, souvenirs have meaning beyond the parameters of the home. Likewise, pilgrims who document their pilgrimage through diaries, photographs or videos find these resources helpful to retrieve the state they were in during the pilgrimage. These documentary practices not only have private but also public meanings. This is evidenced in Caidi, Beazley and Marquez's (2018) study of holy 
selfies. The authors suggest that holy selfies facilitate interactions between Muslims and nonMuslims in a manner close to communitas. We contribute to this research theme by revealing how material objects left behind and brought home can extend communitas beyond the pilgrimage site.

\section{METHODS}

The data presented in this paper emerged from an ethnographic study that investigated the relationship between religion and marketplace structures in Lourdes. Following other pilgrimage scholars (Eade, 1992; Morinis, 1992; Reader and Walter, 1993; Reader, 2014; Terzidou, Scarles and Saunders, 2017, 2018; Turner and Turner, 1978) the ethnographic study encompassed a range of fieldwork methods including participant observation, visuals (videos and photographs) and on-site ad-hoc interviews. Fieldwork totalled 8 weeks during which the first author engaged in multiple roles including participant observer, volunteer and member of an organised pilgrimage group. This encompassed six different visits to Lourdes from April 2011 to May 2013.

In relation to the participant observer role, during four of the visits, the researcher focused on observing the behaviours of pilgrims and the local culture of Lourdes. Early trips throughout 2011 enabled immersion into the context and participation in the rituals associated with Lourdes, whilst a reflective fieldtrip in May 2013 enabled validation of interpretations. Regarding the volunteer role, throughout 2011, the researcher volunteered as an information guide for three weeks. This role provided insight into the role of volunteering, the inner running of the sanctuary, pilgrim behaviour, and was essential to recruiting interviewees. In relation to research ethics, the researcher was open about the ongoing research and her double role of researcher and volunteer. With reference to the organised pilgrimage, in 2012, the researcher travelled as a member of a Scottish pilgrimage group, whom she had been in contact with since 2011. This permitted insight into what it was like to travel as a pilgrim as well as the group pilgrimage perspective. Travelling in this capacity allowed interviewee recruitment of first time and recurrent pilgrims to Lourdes both prior to and post pilgrimage, as well as a shared experience of pilgrimage with the respondents. Together, these different roles permitted holistic understanding of Lourdes culture.

Data collection included in-depth interviews with English-speaking pilgrims. These interviews were conducted in respondents' homes or another location of their choice. By conducting data collection both in Lourdes and respondents' home environments, we adhered to Frey's (2004) suggestion that a more comprehensive understanding of pilgrimage emerges from studies over multiple sites rather than one fixed point. Interviews followed a semistructured flow, meaning they were guided by a predetermined interview structure informed by the fieldwork. Topics included pilgrimage experience, the meaning of Lourdes, sacred and secular aspects of Lourdes and pilgrimage rituals. However, interviews retained flexibility to permit the respondent to become a "conversational partner" (Rubin and Rubin, 1995, p. 1112).

Conducted with twenty-three respondents (see Table 1 for respondent profiles), interviews were predominantly undertaken in Scotland with native English speakers. All of our respondents identified as Catholic with the exception of one who was Christian from the Episcopalian denomination (Iris), and one who viewed herself as spiritual (Yasmina). This sample characteristic is important because it is our respondents' belief in the narrative of Lourdes that drives them to bring material objects home and leave them behind at the pilgrimage site. Some respondents were interviewed multiple times (i.e. a first time pilgrim to Lourdes). Pre-interviews were undertaken about a month prior to travel and on average post- 
pilgrimage interviews were undertaken 6 weeks to a year following a pilgrimage experience. As most respondents were recurrent pilgrims to Lourdes, interviews were filled with stories from across their different Lourdes pilgrimages. This coupled with the time delay following their last pilgrimage allowed for a deeper understanding of how Lourdes continues to influence their daily life. Interviews lasted between 30 minutes and 4 hours, tallying over 1000 pages of transcript. All interviewees signed an informed consent form and to ensure confidentially, pseudonyms have been used in place of respondent's names.

A hermeneutical mode of analysis was adopted, whereby the iterative back and forth between data (emic) and theory (etic) permitted the building of an ever more holistic interpretation. Iterations were built in two ways; intratextual iterations facilitated understanding of each individual transcript whilst intertextual iterations facilitated holistic understanding of the themes emerging in the entire dataset. A good example of "intertextual" iteration, relevant to this paper, is the first author's initial interpretation of the emergent discussion of religious materiality, in particular the religious kitsch objects brought home from Lourdes. Throughout interviews respondents generally discussed these products as tacky thus initial interpretation was that such objects were "negative" signs of commercialisation. However, the iterative backing and forth between the different parts and the whole interview, coupled with field notes and visuals, illuminated these goods to have more symbolic and important meaning than the sole parts of the interview demonstrate. Further to the iterative analysis of data, validity of the interpretation offered was gained through triangulation of data and member checking with depth respondents.

[Table 1.0: Table of Respondents around here]

\section{FINDINGS}

We present the findings in two sections. First, we explore the role of material objects brought home from the pilgrimage site. Second, we reveal the role of material objects left behind at the pilgrimage site.

\section{Material objects brought home from the pilgrimage site}

Findings uncovered that objects purchased in Lourdes not only remind pilgrims of their pilgrimage, but also extend the essence of Lourdes to the home environment. For example, throughout his interview Matthew shared the sense of quietude and calmness he experienced during nightly visits to the Grotto of Massabielle. The Grotto is esteemed as the most sacred part of Lourdes where the apparitions are believed to have occurred. For Matthew, these moments allow him to "think and, or not think. It's one of the few places where you can really totally just zone out from the rest of the world because of how quiet it is." This sense of quietude is something Matthew seeks in daily life, and is re-captured through his interaction with a wooden bracelet he brought home from Lourdes:

"Just a wooden bracelet I picked up. I like wearing it because it reminds me of the place. It reminds me of how I felt, how I feel about the place. I was in work the other day and oh, I could have just throttled this woman - she was driving me crazy. As far as I was concerned, she was just needlessly irritating my life. But I find occasionally if I'm stressed or annoyed, I'll hold the bracelet and "phew" [exhales a breath out] 
and I'll think "just be calm, just calm yourself down, it'll be alright, just take a deep breath." It kind of just reminds me of everything about Lourdes, about the experience, the kind of better person I want to be. And I'll think, "Right. We're okay. We're all right. Just carry on and try and be a better person" (Matthew).

Through holding his bracelet, Matthew gains temporary quietude and calmness akin to the Grotto at Lourdes. His bracelet facilitates recall of memories from his pilgrimage, and aligning with Frey (2004) and Pinto (2007), Matthew's words reinforce the sensory nature of pilgrimage memory. We see this as a form of tangible communitas as the bracelet encourages Matthew to recapture the sensation of calmness associated with his time in Lourdes, reducing his feelings of tension and connecting him better with others. This spontaneous moment of communitas serves to regenerate Matthew and enables him to navigate the normative structures of daily life.

Objects imbued with the sacredness of Lourdes are also symbolic to those who have not been physically present on pilgrimage:

"Do you know I got a pendant with a droplet of Lourdes water within it for my sisterin-law. She is quite posh, and I thought she will think this is tack, but I gave her this as part of her 70th birthday. And she was saying to me the other day on the phone "do you know I have barely got it off, it has helped me." She has been through a lot of bad times, and she said "it has helped me and I just keep touching it when things are getting tense"" (Christine).

Water is one of the symbols of Lourdes and pilgrims believe that Lourdes water has healing and sacred properties. Christine's sister-in-law gains comfort from her hard times by holding the pendant containing Lourdes water. Both Matthew's bracelet and the necklace are objects of tactility and it is through the embodied practice of touch that their meanings come to the fore. Beliefs are materialised within these objects (Roberts, 2010) and they can be used as a form of compensatory control, whereby through giving up one's agency to deity, the bracelet and necklace materially helps to displace anxiety and create "a sense of order and non-randomness in the world" (Shepherd and Kay, 2018, p. 469). Christine's example also illustrates how pilgrims can extend tangible communitas through practices of gift-giving by indirectly connecting those at home to Lourdes.

Christine's assumption that the pendant may be perceived as "tack" due to her sister-in-law being "quite posh", is indicative of how kitsch is oft aligned with taste and class debates (i.e. Baudrillard, 2012; Broch, 1968; Dorfles, 1968). Holliday and Potts (2012) argue that kitsch objects can help us to escape the realities, worries and fears of everyday life. Christine's sister-in-law's continued use and reliance on the pendant during her "bad times", highlights such escapism, outlining a shattering of the kitsch class debate. Such shattering and symbolism of kitsch objects was indicative across much of our data:

"The tackiest thing I have is a glittery Our Lady statue [statue of the Mother of Jesus Christ] that changes colour depending on the weather. So, it is blue and if it goes sunny it turns purple, it is really nice! I bought that because I thought to myself, "that's really nice, that's glittery." That's the tackiest thing I have ever bought [laughs]. I've still got it in my room, it sits on my window ledge, I've had that for years now. I have over the years moved it and thought about binning it, but every time I cannot bring myself to let go of it. It is just a part of my room, my home, of me now and I can't explain it but I cannot part with it" (Lilly). 
Lilly's laughter at the sparkling Our Lady statue and her use of the descriptor "tacky" illustrates her opinion of the object as kitsch. Lilly bought the statue during her first visit to Lourdes with her mother. When she was 17, Lilly's mum was diagnosed with cancer and the whole family travelled to Lourdes to pray for healing. Unfortunately, Lilly's mother passed away and her affinity to Lourdes is tied to memories of this trip: "it's just a very special place because like I shared it with my mum, it is kind of special to my family, not just me, to my family. It's so hard to explain, it's just you're drawn back all the time and, ok, there are very sad memories there but there's happy memories too." Lilly's inability to let go of the statue highlights that tangible communitas manifests through the statue, indirectly connecting her to her mum's memory and their time together in Lourdes. Her difficulty in explaining her relationship with the statue points towards its extra-discursive affects illustrating how its significance clearly extends beyond its market value. The kitsch nature of these religious objects is not a barrier to communitas, rather, their "lack of pretentions or pretentiousness" (Turner, 1982, p. 48) facilitates spontaneous eruptions of communitas.

A further example is evident in Andrea's attachment to a luminous Our Lady statue brought home from Lourdes:

"I know it's luminous and I know it is "bondieuserie" (French for religious kitsch) but when I wake during the night and see the statue shining I feel protected and safe knowing Our Lady is watching me" (Ad-hoc interview with volunteer at Lourdes).

For Andrea, the luminous statue projects an atmosphere of safety and protection, through what Rantala and Valtonen (2014) describe as sensing materiality during sleep. The statue is symbolic of the sense of communitas associated with the safety and security of Lourdes. Our findings overwhelmingly suggest that the social landscape of Lourdes encapsulates a familiarity and trust amongst pilgrims that is expressed as being a "home away from home," "comfortable", "homely", and "safe." This sense of "homeyness" (McCracken 2005) is imbued in the statue and helps Andrea to replicate these feelings at home. In this way, the presence of Lourdes "speaks" (Cox 2018, p. 36) through material objects brought home from the pilgrimage site and helps pilgrims to "mediate his or her relationship with the larger world" (McCracken 2005, p. 46).

The data presented above exemplifies how material objects facilitate a spontaneous, subtle and individual form of communitas. Pilgrim's personal attachment to the physical objects brought home from Lourdes permits a temporal re-capturing of the Lourdes pilgrimage. Next, we consider how spontaneous forms of communitas also emerge through material objects left behind.

\section{Material objects left behind at the pilgrimage site}

Our findings in this section focus on material objects left behind by pilgrims in the Grotto of Massabielle, the most sacred part of Lourdes. We consider the rituals associated with (1) posting petitions (written prayers) in a box in the Grotto and (2) lighting candles at or near to the Grotto.

The posting of petitions is a ritual of dialogue with Deity. Petition stems from the Latin petitio, meaning a request, and petere, meaning to move forward. Simply defined, petitions are personal requests for religious intervention to life problems. The petitions posted by our respondents in the Grotto are most often written by family, friends and acquaintances at home who have requested the pilgrim to carry out this ritual on their behalf. Petitions vary 
in length with some written briefly on scraps of paper while others extend to pages and pages of text. Jacob and Garry, both school teachers, explain the positive response they received when they offered to transport petitions to Lourdes:

"All the people in the school were really interested and a lot of parents were interested. The head-teacher sent out a note saying "if anybody would like a petition taken over and put into the Grotto, then hand it into school and Mr. McCauly will take it over." So, when we were going we had hundreds and hundreds. Parents from the school were coming in and saying, "this is from his grandma and this is from the woman next door, and this is from the old lady up the road" and so in the end we went with pages and pages. It was amazing, I couldn't believe the response. It ended up we had three or four big A4 envelopes, and, I mean, each of them was filled up by six or seven inches full of petitions, it was unbelievable, we must have put in, honestly, hundreds" (Jacob).

"I just sent out an email saying, "listen going to Lourdes if anybody wants any petitions handed in, post them in my pigeon box" and every day I was getting floods and floods of folk posting things in. Some people were putting them on prayer cards or you know bigger envelopes with them all sealed, other people were just writing them on scraps of paper and handing them to me in the corridor" (Garry).

In posting "hundreds" and "floods" of petitions for others, Jacob and Garry facilitate access to the pilgrimage site for those who cannot be physically present themselves. In dissolving physical distance, the transportation of petitions allows those at home to connect with the narrative of Lourdes. Petitions are intended to be a means of private communication with Deity, meaning they are not read by others. This anonymity is important because it allows freedom of expression and temporary escape from normative structure. Respondents outlined feeling "privileged," "honoured" and "touched" at being entrusted to transport people's petitions. The role of posting petitions indirectly yet deeply connects pilgrims with those at home, a central aspect of spontaneous communitas.

During her annual pilgrimage to Lourdes, Kitty volunteers in the petitions office. She explains that she would never read others' petitions but can't help notice their "tear stained pages." This points towards the emotional intensity of this ritual. The cathartic benefits of writing are well documented in terms of the therapeutic value associated with disclosure of one's problems (e.g. Pennebaker, 1997). Our findings reveal that respondents do not believe that writing and posting their prayers in Lourdes increases the likelihood that they will be heard and answered, but nevertheless, the process of doing this is special, particularly because of the religious significance of the Grotto where they are placed. As Anne explains:

"Our prayers are heard wherever we are, as we all know, but there is something special about them landing in the place, you know it is just a human thing. I think that it is a lovely thing and makes a lot of sense, and does it mean the prayers are heard better? Well no obviously not, but actually, it is a nice thing to do" (Anne).

The posting of petitions elsewhere would not hold the same meaning because of the historical significance stemming from the belief that the Mother of Jesus Christ appeared there in 1858 . As Cox (2018) suggests, material culture permits land to speak and, through the petitions, the sacred experience of the pilgrimage site speaks to those at home. 
Anne's sentiments of the importance of prayers "landing" in the Grotto is shared by Brendan, a priest who works at Lourdes. Part of Brendan's daily activity is to receive and print emailed petitions from believers around the world who desire their prayers to land in the Grotto:

"One of the lovely things I get are emails, and people write to Lourdes with their troubles looking for prayers. I've had five emails in the last month from a lady from the Far East whose husband sometimes beats her up, she feels that he is having an affair and she wants her marriage saved. Somehow just to have her petitions printed and brought to the Grotto, it's helping her with life. I hear from a wife in New York whose husband has brain cancer, and a lady in the North of Ireland who is afraid of dying. I can assure you that when I check again there will be an email for me asking for prayers, those are important - that's important to me. I write to them and that is very important, all I say to them is that I go to the Grotto every day with their petitions and I pray for them there every day" (Brendan).

Despite geographic separation, spontaneous communitas is evident in Brendan's empathy and prayer for those around the world who seek solace from Lourdes and become "connected experientially" (Cox, 2018, p. 43) through the opportunity to share in the petitions ritual. Prior work reveals that pilgrims benefit from participation in rituals that promote therapeutic release (Harris, 2013; Higgins and Hamilton, 2019). We extend this perspective and suggest that therapeutic release is not only achieved by pilgrims who are physically present at the pilgrimage site. Rather, therapeutic release can be extended at an individual level to those at home.

[Figure 1: Candles in the Grotto around here]

Another type of material object left behind at Lourdes are candles (see figure 1). Some 700-800 tonnes of candles are burned annually at Lourdes. Similar to petitions, the ritual of lighting candles is often directed at other people who are not physically present at the pilgrimage site:

"For many I think they feel that they cannot physically get there, but like to be associated with what happens, and just simply lighting a candle does that" (Paul).

"People light candles for whoever, for their parents, for their grandma, for their friend, for someone who asks them" (Matthew).

Once again, the placing of candles in or near to the Grotto is significant because this is deemed a sacred space that speaks to many. Candles are a form of votive offering in anticipation of prayers being answered. Recent research suggests that votive depositions are part of a process of social memory (Winter, 2019). The temporal aspect of votive offerings is equally evident in our study because the ritual of lighting candles has historical significance and stems from the belief in Lourdes etymology of The Miracle of the Candle. This "echo of Bernadette" (Thomas et al., 2018) stems from the apparition of $7^{\text {th }}$ April 1858 during which Bernadette Soubirous touched the flame of a candle for over ten minutes without coming to any harm (Lauretin, 1999).

However, lighting candles is not only about looking back to the apparitions but also looking forward and thus combining remembrance of the past with hopes and requests for the future. Miriam explains what lighting candles at Lourdes means to her: 
"it's just a moment to think about that person from home and have them in your thoughts and explain that to God, to say this is who I'm thinking about, this is who this is for, this is what I want, you know? This is what I'm thinking about and I want you to think about them too, or something like that. Just a moment to concentrate on them in that way" (Miriam).

The displays of candles that are evident in Lourdes (figure 1 provides an example) represent the collective voice of pilgrims and the shared sense of connection to this sacred space. Miriam outlines how candles prompt consideration and empathy for others. Equally, Rachael ponders, "what are the stories behind those candles?" Here, once again we witness a more individualised than group form of communitas whereby individual reflection upon others at home permits pilgrims to "look through one another's eyes" (Cox, 2018, p. 49). This links them empathetically, through the tangible candle, with those they reflect upon, thus creating a spontaneous and subtler sense of communitas.

\section{DISCUSSION}

Communitas has featured in pilgrimage theory for decades (Turner and Turner, 1978). Indeed, Collins-Kreiner's (2016) product lifecycle (PLC) analysis of pilgrimage tourism positions communitas within the introduction stage of research. Collins-Kreiner (2016) calls for pilgrimage tourism researchers to break free from conceptual "basic features" (2016, p. 330) as a means of rejuvenating scholarly insight. In prioritising its spontaneous form, this paper extends the capacity of communitas, by breaking free from the normative communitas understandings that have to date dominated pilgrimage tourism scholarship.

The link between religion and materiality is well established, however excepting the work of Cox (2018), no research within the context of pilgrimage specifically explores the link between communitas and materiality. Cox (2018) claims that tangible communitas occurs when material culture manifests in a manner permitting land to speak. However, although discussed from a perspective of detachment, Cox's version of tangible communitas remains fixed to the pilgrimage site. Vásquez (2011, p. 323) suggests that a material perspective is helpful for exploring the "portability of religion." Our findings are particularly concerned with the portability of communitas. Such portability is indicative of an individual form of communitas, whereby pilgrims are individually connected with Lourdes. However, this paper also illustrates how material objects taken from and left behind during pilgrimage speak to both those present and those at home, enhancing interpersonal relationships and feelings of deep connection between people, object and place. Consequently, spontaneous communitas, as offered here, is experienced at both the individual and social level.

Many scholars believe that liminality is crucial to the generation of communitas (i.e. Roseman and Badone, 2004; Turner and Turner, 1978). However, we have revealed that even within the structured and rule-governed world of everyday life, communitas can occur, albeit in spontaneous and subtler forms. In revealing that communitas can traverse spatial boundaries, our findings suggest a decoupling of communitas and liminality. This insight further illustrates how structure and communitas can co-exist. Thus, reinforcing how communitas, structure and contestation are not nemeses but allies that "dialectically inform each other" and "keep each other in check" (Di Giovine, 2011, p. 262). Furthermore, this paper marks a point of departure from Turner's (1969) predominant alignment of spontaneous communitas with pleasure, as our data overwhelmingly illustrates emotions of anxiety, stress, grief, fear and safety. Thus, the spontaneous communitas experienced by 
pilgrims of the Lourdes pilgrimage is just as likely to occur during moments and durations of angst as during moments of pleasure.

Pilgrimage research prioritising the return home often suggests feelings of tension (Kaell, 2014), whereby on returning home pilgrims become quickly reincorporated into societal structures that bracket the pilgrimage experience (Buzinde et al. 2014; Frey, 2004). This paper uncovers no such tension, but rather is suggestive of a fluid reincorporation of pilgrimage to the home environment. Kaell (2014) uncovers religious souvenir displaying and gift giving to be conspicuous signs of religiosity. This paper reveals that even when given as gifts, material objects are not utilised as conspicuous markers of religiosity. Rather they are inconspicuously incorporated into one's life, becoming private and personal conduits of spontaneous communitas that interrupt the mundane status quo of normative structure.

In profiling the leaving behind of material objects at Lourdes, this paper provides further insight into how pilgrimage centres can be delocalised from their fixed locations, and "translated to new places, at different scales" (Bajc et al., 2007, p. 328). For those without first-hand direct experience, material gift-giving and the rituals of posting petitions and lighting candles indirectly connects them to the pilgrimage site, permitting them a similar sense of emotional release and reprieve (i.e. from anxiety) as those who physically journey to Lourdes. Intersubjective interactions at a pilgrimage site enables pilgrims to feel part of a whole (Terzidou et al., 2018) yet material objects can act as a vehicle for intersubjective interaction for those who are physically distant. We thus build on prior work and suggest that some of the therapeutic benefits of pilgrimage (Harris, 2013, Higgins and Hamilton, 2019) can be extended to those at home who are physically absent from the site.

Finally, this paper extends understanding of the value of religious souvenirs. Like much religious kitsch, the objects discussed in this paper are not expensive in monetary terms. However, our findings show that their value extends far beyond their market value. Scholarly discussion of religious souvenirs is often shackled to a taste debate, whereby kitsch is perceived as the antithesis of good taste (Baudrillard, 2012; Broch, 1968; Dorfles, 1968). Taste manifests as a performative practice but our findings move beyond visible aesthetics and instead draws attention to the sensory and extra-discursive features of religious material kitsch. These features emphasise the relational value of religious kitsch objects in terms of facilitating the inter-relationship between the pilgrimage site and the home environment. Religious kitsch is central to meaning-making in everyday life by connecting pilgrims with deity and also to other people (acquaintances, family and friends), both living and dead. Thus, whereas previous research distinguishes between special religious materiality (such as objects blessed) (Paraskevaidis and Andriotis, 2015), we show how spiritual value has a broader scope. Spackman (2005, p. 411) queries "is there more to a plastic Jesus than plastic?" This paper answers yes, for our findings illuminate that beneath the cacophony of plastic, luminosity and glitter, there can lie a kaleidoscope of symbolism important to one's sense of self, and a pathway to experiencing an individual, subtler form of spontaneous communitas.

\section{CONCLUSION}

To conclude, this paper offers to pilgrimage tourism research the following contributions. Firstly, through the profiling of tangible communitas we extend the capacity of communitas by prioritising its spontaneous over its normative form. Our material perspective offers insight into the neglected relationship between materiality and communitas. Findings uncover communitas to have portability, which in turn illustrates that communitas can be experienced in normative structure and de-coupled from liminality. Furthermore, spontaneous communitas is often aligned with pleasure. The findings from this study, however, outline 
how communitas in its spontaneous form can equally arise during moments of angst.

Secondly, the paper's focus on religious material objects both taken and left behind whilst on pilgrimage provides further insight into how pilgrimage can be delocalised from its fixed spatiality and incorporated in the home environment. Finally, the material focus of the paper offers draws attention to the sensory and extra-discursive value of religious material kitsch.

This study is based on only one pilgrimage context and we are aware that different contexts and religions may offer differing insights. We call for future research to further extend the capacity of communitas by investigating the lesser researched forms of communitas (i.e. spontaneous and ideological). Such research may yield insight into new and novel forms of communitas that are representative of society and culture in the $21^{\text {st }}$ century. Furthermore, future research should investigate the variegated meanings of home, pilgrimage and materiality in other contexts and religions beyond the Western Christian perspective offered here. In particular, pilgrimage is predicted to rise exponentially within Buddhism contexts (Coningham, 2016). Given this trend, future research should seek to understand the role of religious materiality in such sites.

\section{REFERENCES}

Anderson, L.F., \& Littrell, M.A. (1995). Souvenir-Purchase Behaviour of Women Tourists. Annals of Tourism Research, 22, 328-348. https://doi.org/10.1016/0160-7383(94)00080-8

Andriotis, K. (2009). Sacred site experience: A phenomenological study. Annals of tourism Research, 36 (1), pp.64-84. https://doi.org/10.1016/j.annals.2008.10.003

Badone, E., \& Roseman, S. (Eds.). (2004). Intersecting journeys: The anthropology of pilgrimage and tourism. Champaign: University of Illinois Press.

Bajc, V., Coleman, S., Eade, J. (2007). Introduction: Mobility and Centring in Pilgrimage, Mobilities, 3 (2-3), 321-329. https://doi.org/10.1080/17450100701633742

Baudrillard, J. (2012). The Consumer Society, Myths and Structures. London: Sage.

Belk, R.W., Wallendorf, M., \& Sherry, J.F. Jr. (1989). The Sacred and the Profane in Consumer Behaviour: Theodicy on the Odyssey. Journal of Consumer Research, 16 (1), 1-38. https://doi.org/10.1086/209191

Belhassen, Y. (2009). Fundamentalist Christian pilgrimages as a political and cultural force. Journal of Heritage Tourism, 4 (2), 131-144. https://doi.org/10.1080/17438730802366516

Belhassen, Y., Caton, K., \& Stewart, W.P. (2008). The Search for Authenticity in the Pilgrim Experience. Annals of Tourism Research, 35, 668-689. https://doi.org/10.1016/j.annals.2008.03.007

Broch, H. (1968). Notes on the Problem of Kitsch. In Dorlfes, G. (Ed.), Kitsch: The World of Bad Taste (pp. 49-76) New York: Universe Books.

Buzinde, C.N., Kalavar, J.M., Kohli, N., Manuel-Navarrete, D. (2014). Emic understandings of Kumbh Mela pilgrimage experiences, Annals of Tourism Research, 49 (6), 1-18. https://doi.org/10.1016/j.annals.2014.08.001

Carr, N. (2002). The Tourism-Leisure Behavioural Continuum, Annals of Tourism Research, 29 (4), 972-986. https://doi.org/10.1016/S0160-7383(02)00002-6 
Caidi, N. (2019). Pilgrimage to Hajj: An Information Journey. The International Journal of Information, Diversity, \& Inclusion, 3 (1), 44-76. https://doi.org/10.33137/ijidi.v3i1.32267

Caidi, N., Beazley, S. and Marquez, L.C. (2018). Holy selfies: Performing pilgrimage in the age of social media. The International Journal of Information, Diversity, \& Inclusion, 2 (1/2), 831. https://doi.org/10.33137/ijidi.v2i1/2.32209

Coleman, S., Eade, J. (2018). Pilgrimage and Political Economy: Introduction to a Research Agenda. In Coleman, S., Eade, J, (Ed.), Pilgrimage and Political Economy: Translating the Sacred (pp. 1-20), Oxford and New York, Berghahn Books.

Collins-Kreiner, N. (2016) The lifecycle of concepts: the case of 'Pilgrimage Tourism', Tourism Geographies, 18 (3), 322-334. https://doi.org/10.1080/14616688.2016.1155077

Collins-Kreiner, N. (2010). The Geography of Pilgrimage and Tourism: Transformation and Implications for Applied Geography. Applied Geography, 30 (1), 153-164. https://doi.org/10.1016/j.apgeog.2009.02.001

Coningham, R. (2016). "Social and Economic Impacts of Pilgrimage in South Asia”, https://www.dur.ac.uk/cech/unescochair/workshops/pilgrimage/

Cox, N. (2018). Tangible Communitas: The Los Angeles Wisdom tree, Folklore and NonReligious pilgrimage, Western Folklore, 77 (Winter), 29-55.

Di Giovine, M.A. (2011). Pilgrimage: Communitas and Contestation, Unity and Difference - An Introduction, Tourism Review, 59 (3), 247-269.

Di Giovine, M.A. (2012). Padre Pio for sale: souvenirs, relics, or identity markers? International Journal of Tourism Anthropology, 2 (2), 108-127. https://doi.org/10.1504/IJTA.2012.048992

Dorfles, G. (1968). Kitsch: The World of Bad Taste. New York: Universe Books

Eade, J. (1992). Pilgrimage and Tourism at Lourdes, France. Annals of Tourism Research, 19, 18-32. https://doi.org/10.1016/0160-7383(92)90104-W

Fargues, C. (2011). Lourdes. France, MSM Publications.

Frey, N. L. (2004). Stories of the Return: Pilgrimage and its Aftermath. In Badone, E. (Ed.), Intersecting Journeys: The Anthropology of Pilgrimage and Tourism (pp. 89-109). Berkeley, University of California Press.

Gilmore, L. (2005). Embers, Dust and Ashes: Pilgrimage and Healing at the Burning Man Festival. In Dubisch, J., Winkleman, M. (Eds.). Pilgrimage and Healing, (pp. 155-177) Arizona, University Arizona Press.

Greenfield, S.M. Calvacante, A.M. (2005). Pilgrimage Healing in Northeast Brazil: A Culturalbiological Explanation. In Dubisch, J., Winkleman, M. (Eds.). Pilgrimage and Healing, (pp. 3-23) Arizona, University Arizona Press.

Haldrup, M. (2017). Souvenirs: Magical Objects in Everyday Life, Emotion, Space and Society, 22, 52-60. https://doi.org/10.1016/j.emospa.2016.12.004

Harris, A. (2013). Lourdes and holistic spirituality: Contemporary Catholicism, the therapeutic and religious thermalism. Culture and Religion, 14 (1), pp.23-43.

https://doi.org/10.1080/14755610.2012.756411 
Higgins, L. and Hamilton, K. (2019). Therapeutic Servicescapes and Market-Mediated Performances of Emotional Suffering, Journal of Consumer Research, 45 (6), 1230-1253. https://doi.org/10.1093/jcr/ucy046

Holliday, R., Potts, T. (2012). Kitsch! Cultural Politics and Taste, UK, Manchester University Press.

Hudman, L.E., \& Jackson, R.H. (1992). Mormon Pilgrimage and Tourism, Annals of Tourism Research, 19, pp. 107-121. https://doi.org/10.1016/0160-7383(92)90110-B

Huseman, K.C., Eckhardt, G.M. Grohs, R., \& Saceanu R. E. (2016). The dynamic interplay between structure, anastructure and antistructure in extraordinary experiences, Journal of Business Research, 69 (9), 3361-3370. https://doi.org/10.1016/j.jbusres.2016.02.008

Husemann, K.C. and Eckhardt, G.M. (2019). Consumer Deceleration, Journal of Consumer Research, 45 (6), 1142-1163. https://doi.org/10.1093/jcr/ucy047

Jackowski, A., \& Smith, V.L. (1992) Polish Pilgrim-Tourists, Annals of Tourism Research, 19, 92-106. https://doi.org/10.1016/0160-7383(92)90109-3

Kaell, H. (2012). Of gifts and grandchildren: American Holy Land Souvenirs, Journal of Material Culture, 17 (2), 133-151. https://doi.org/10.1177\%2F1359183512443166

Kaell, H. (2014). Walking Where Jesus Walked, New York and London, New York University Press.

Kaufmann, S. K. (2005). Consuming Visions: Mass Culture and the Lourdes Shrine, Ithaca and London, Cornell University Press.

King, C. (2005). Pilgrimages, promises and ex-votos: Ingredients for healing in Northeast Brazil. In Dubisch, J., Winkleman, M. (Eds.). Pilgrimage and Healing, (pp. 49-68) Arizona, University Arizona Press

Larsen, J. (2008). De-exoticizing Tourist Travel: Everyday Life and Sociality on the Move, Leisure Studies, 27(1), 21-34. https://doi.org/10.1080/02614360701198030

Lauretin, R. (1999). Bernadette Speaks: A Life of Saint Bernadette Soubirous in Her Own Words. Boston, Pauline Books and Media.

McCracken, G. (2005). Culture and Consumption II: Markets, Meaning and Brand Management. USA: Indiana University Press

McDannell, C. (1995). Material Christianity: Religion and Popular Culture in America. USA: Yale University Press.

Morinis, A. (1992). Sacred Journeys: The Anthropology of Pilgrimage, Westport: Greenwood Press.

Morgan, D. (2010). Religion and Material Culture: The Matter of Belief, London, Routledge.

Moufahim, M. and Lichrou, M. (2019). Pilgrimage, Consumption and Rituals: Spirituality Authenticity in a Shia Muslim Pilgrimage, Tourism Management, 70 (1), 322-332. https://doi.org/10.1016/j.tourman.2018.08.023

Notermans, C. and Jansen, W. (2011). Ex-votos in Lourdes: contested materiality of miraculous healings. Material Religion, 7 (2), 68-192.

https://doi.org/10.2752/175183411X13070210372823 
Parashevaidois, P. and Andriotis, K. (2015). Values of souvenirs as commodities, Tourism Management, 48, 1-10. https://doi.org/10.1016/j.tourman.2014.10.014

Pennebaker, J. (1997), Writing about emotional experiences as a therapeutic process, Psychological Science, 8 (3), 162-166. https://doi.org/10.1111\%2Fj.14679280.1997.tb00403.x

Pfaffenberger, B. (1979). The Kataragama Pilgirmage: Hindu-Buddhist Interaction and its Significance in Sri Lanka's Polyethnic Social System. Journal of Asian Studies, 38 (2), 253270. DOI: $10.2307 / 2053418$

Pinto, P.G. (2007). Pilgrimage, Commodities, and Religious Objectification: The Making of Transnational Shiism between Iran and Syria, Comparative Studies of South Asia, Africa and the Middle East, 27 (1), 109-125. http://dx.doi.org/10.1215/1089201x-2006-047

Preston, J.J. (1992). Spiritual Magnetism: An Organizing Principle for the Study of Pilgrimage. In Morinis, A. (Eds). Sacred Journeys: The Anthropology of Pilgrimage, (pp. 31-46). Westport: Greenwood Press.

Rantalla and Valtonen (2014). A rhythmanalysis of touristic sleep in nature, Annals of Tourism Research, 47 (4), 18-30. https://doi.org/10.1016/j.annals.2014.04.001

Reader, I, (1993). Conclusions. In Reader, I. and Walter, T. (Eds.), Pilgrimage in in Popular Culture, (pp. 220-246). London: The Macmillan Press.

Reader, I., \& Walter, T. (1993). Pilgrimage in Popular Culture. London: The Macmillan Press.

Reader, I., (2014). Pilgrimage in the Marketplace. London: Routledge.

Rinschede, G. (1992). Forms of Religious Tourism. Annals of Tourism Research, 19, 51-67. https://doi.org/10.1016/0160-7383(92)90106-Y

Roberts, M.N. (2010). Tactility and transcendence: Epistemologies of touch in African art and spiritualities. In Morgan, D. (Ed.). Religion and Material Culture: The Matter of Belief, (pp. 77-96) London, Routledge.

Rubin, H.J., \& Rubin, I.S. (1997). Qualitative Interviewing: the Art of Hearing Data, CA Thousand Oaks: Sage.

Sallnow, M.J. (1981). Communitas Reconsidered: The Sociology of Andean Pilgrimage, Man,16 (2), 163-182. DOI: 10.2307/2801393

Santana, J. Botelho, D. (2018). “If it comes from Juazeiro, it's blessed!”: Liquid and Solid attachments in systems of object itineraries of pilgrimages, Journal of Marketing Management, 35 (5-6), 514-539. https://doi.org/10.1080/0267257X.2019.1592210

Scott, L., \& Maclaren, P. (2013). Consuming the Mists and Myths of Avalon: A Case Study of Pilgrimage in Glastonbury. In D. Rinallo, L. Scott, \& P. Maclaren (Eds.), Consumption and Spirituality (pp. 95-210). London: Routledge.

Shepherd, S. Kay, A.C. (2018). "Jesus, take the wheel”: The appeal of spiritual products in satiating concerns about randomness, Journal of Marketing Management, 35 (5-6), 467-490. https://doi.org/10.1080/0267257X.2018.1556225

Spackman, B. (2005). A Profound Weakness: Christians and Kitsch. Ontario: Piquant. 
Strausberg (2011). Religion and Tourism: Crossroads, Destinations and Encounters, London: Routledge.

Thomas, S., White, G.R.T., Samuel, A. (2018). To pray and to play: Post-postmodern pilgrimage at Lourdes, Tourism Management, 68 (1), 412-422.

https://doi.org/10.1016/j.tourman.2018.03.021

Turner, V., \& Turner, E.L.B. (1978). Image \& Pilgrimage in Christian Culture. New York: Columbia University Press.

Turner, V. (1969). The Ritual Process: Structure and Anti-Structure, USA: Aldine Transaction.

Turner, V. (1982). From Ritual to Theatre: The Human Seriousness of Play, New York, PAJ Publications.

Turley, D. (2013). "Forming Sacred Places and Possessions: Pilgrims at St. Brigid's Holy Well. In Rinallo, D., Scott, L., Maclaren, P. (Eds.), Consumption and Spirituality, (pp. 165-177) London: Routledge.

Terzidou, M., Scarles, C. and Saunders, M.N. (2017). Religiousness as tourist performances: A case study of Greek Orthodox pilgrimage. Annals of Tourism Research, 66 (1), 116-129. https://doi.org/10.1016/j.annals.2017.06.009

Terzidou, M., Scarles, C. and Saunders, M.N. (2018). The complexities of religious tourism motivations: Sacred places, vows and visions. Annals of Tourism Research, 70 (1), 54-65. https://doi.org/10.1016/j.annals.2018.02.011

Van Lear, T., Izberk-Bilgin, E. (2019). A discourse Analysis of Pilgrimage Reviews, Journal of Marketing Management, 35 (5-6), 586-604. https://doi.org/10.1080/0267257X.2018.1550434

Vasquez, M.A. (2011). More than Belief: A Materialist Theory of Religion. Oxford, Oxford University Press.

Van Gennep, A. (1960). The Rites of Passage, London, Routledge.

Winkelmam, M. and Dubisch, J. (2005). Introduction: The Anthropology of Pilgrimage. In Dubisch, J., Winkleman, M. (Eds.). Pilgrimage and Healing, (pp. ix-xxxvi) Arizona, University Arizona Press.

Winter, C. (2019). Pilgrims and votives at war memorials: a vow to remember, Annals of Tourism Research, 76, 117-128. https://doi.org/10.1016/j.annals.2019.03.010 


\section{FIGURES}

Figure 1: Candles in the Grotto

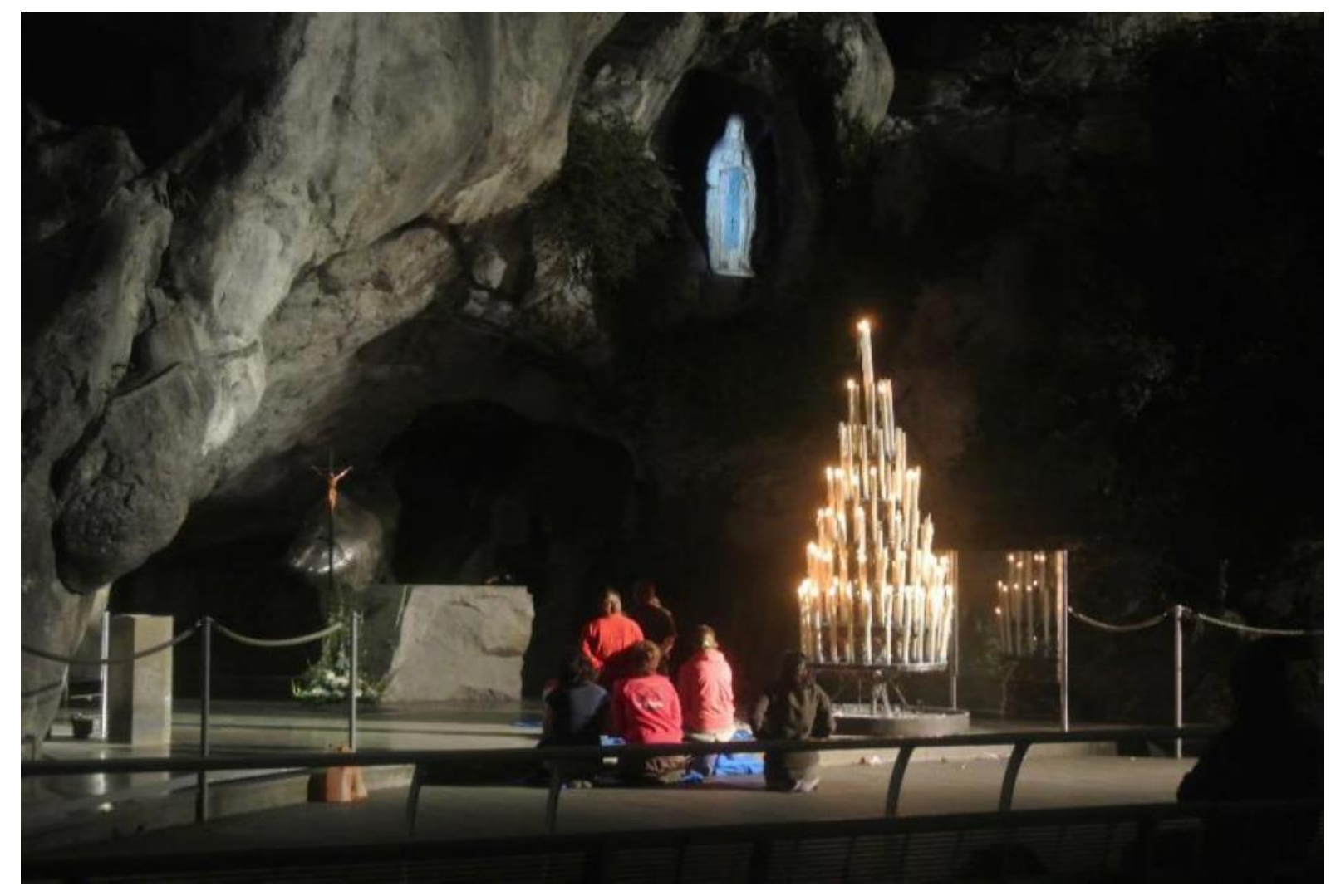




\section{TABLES}

Table 1: Table of Respondents

\begin{tabular}{|l|l|l|l|l|}
\hline Name & Age & Nationality & Occupation & No of Times to Lourdes \\
\hline Danielle & 18 & Scottish & Student & First time \\
\hline Frances & 17 & Scottish & Student & First time \\
\hline Brendan & 73 & Irish & Priest at Lourdes & Lives in Lourdes \\
\hline Kelly & 35 & Scottish & Teacher & 6 \\
\hline Lisa & 19 & Scottish & Student & 5 \\
\hline Lilly & 24 & Scottish & Teacher & 7 \\
\hline Miriam & 25 & Scottish & Marketing Manager & 11 \\
\hline Matthew & 22 & Scottish & Student & 5 \\
\hline Marie & 54 & Scottish & Historian & $50+$ times \\
\hline Patricia & 93 & Scottish & Retired Teacher & $60+$ times \\
\hline Phillip & 61 & Scottish & Business Man & $21+$ times \\
\hline Pierre & 40 & French & Hotel owner in Lourdes & Lourdes Native \\
\hline Anne & 37 & Scottish & Nun & 8 \\
\hline Yasmina & 27 & French & Volunteer at an Ashram & First time \\
\hline Garry & 25 & Scottish & Teacher & 6 \\
\hline Jacob & 26 & Scottish & Teacher & 12 \\
\hline Veronica & 60 & Scottish & Retired teacher & 11 \\
\hline James & 63 & Scottish & Doctor & 11 \\
\hline Paul & 63 & Scottish & Teacher & 10 \\
\hline Christine & 63 & Scottish & Retired administrator & 13 \\
\hline Kitty & 66 & Scottish & Retired teacher & 10 \\
\hline Iris & 67 & Scottish & Retired administrator & 8 \\
\hline Rachael & 74 & Scottish & Retired teacher & 10 \\
\hline
\end{tabular}

